\title{
THE DETERMINANTS OF CORPORATE BOND RATING IN INDONESIA
}

\author{
Harisya Amran \\ Fakultas Ekonomi \\ Email: hamran@gmail.com
}

\begin{abstract}
This research aims to identify the factors affecting obligation rank on manufacturing corporations. The factors investigated in this research include leverage ratio, liquidity ratio, profitability ratio, activity ratio, and maturity. The population in this research is all non-financial corporations registered in Indonesia Stock Exchange, which has been registered for 5 years, and has published obligations. 47 corporations meet those criteria and become the research sample. Data analysis on this research use logistic regression analysis. The result shows that from five variable researched, only one influence the obligation rank, which is profitability ratio. This result contributes to both theory and practitioners.
\end{abstract}

Keywords: bond rating, leverage ratio, liquidity ratio, profitability ratio, activity ratio, and maturity, logistic regression 


\section{PENDAHULUAN}

Obligasi merupakan salah satu aset keuangan yang berkembang hingga saat ini dan dapat diperdagangkan serta cukup menarik bagi para pemilik modal dalam melakukan investasi pada pasar modal. Bagi pemilik modal, obligasi lebih menarik dari segi return yang diperoleh dibandingkan berinvestasi pada saham. Para investor akan memperoleh bunga yang besarnya telah ditentukan selama periode obligasi, sehingga obligasi dapat disebut sebagai investasi yang memberikan penghasilan tetap. Pembayaran bunga obligasi juga harus didahulukan sebelum penerbit obligasi membayarkan dividen kepada para pemegang saham. Seperti halnya investasi saham, pada obligasi juga memiliki peluang mendapatkan capital gain dengan melakukan penjualan obligasi di pasar sekunder. Dalam hal terjadi likuidasi pada perusahaan, pemilik obligasi juga memperoleh hak pertama atas asset yang dimiliki perusahaan dibandingkan pemilik saham. Sehingga investasi pada obligasi lebih aman dibandingkan bila pemilik modal berinvestasi pada saham. Bagi perusahaan, penerbitan obligasi menjadi salah satu pilihan memperoleh dana dengan biaya yang lebih murah dibandingkan bila meminjam atau kredit di bank. Selain itu kelebihan obligasi bagi perusahaan penerbit obligasi adalah posisi kepemilikan perusahaan tidak akan mengalami perubahan dan bagi manajemen perusahaan penerbit obligasi memiliki fleksibilitas yang lebih tinggi dalam memanfaatkan dana hasil penerbitan obligasi karena sifat utang yang dapat berjangka waktu panjang.

Walaupun instrumen obligasi termasuk aman untuk melakukan investasi, namun investasi obligasi tetap mempunyai potensi risiko. Risiko obligasi bisa berupa kegagalan perusahaan penerbit obligasi dalam pembayaran bunga/kupon obligasi tepat waktu. Dan risiko yang paling ditakuti investor adalah perusahaan penerbit obligasi tidak mampu membayar kewajiban pokok utangnya.

Sebagai contoh fenomena yang ada di Indonesia adalah kasus yang terjadi pada salah satu emiten dimana PT Bumi Resources Tbk (BUMI) gagal membayar bunga obligasi tepat waktu pada Oktober 2014. PT Bumi Resources Tbk seharusnya membayarkan bunga obligasi terbitan oleh anak 
perusahanya yaitu Bumi Investment Pte Ltd, pada 6 Oktober 2014. Standard \& Poor's Ratings Services (S\&P) yang merupakan lembaga pemeringkat telah memangkas rating surat utang jangka panjang PT Bumi Resources Tbk (BUMI) senilai US\$ 700 juta dari CCC- menjadi D. Adapun bunga obligasi sebesar 10,75 persen per tahun dan pembayaran dilakukan setiap enam bulan, pada bulan April dan Oktober. Dengan demikian, beban bunga yang harus dibayarkan sebesar US\$ 73,5 juta (beritasatu.com, 2014). Demikian juga terjadi pada PT Bakrieland Development Tbk (ELTY) melakukan penundaan pembayaran pelunasan terhadap utang pokok dan bunga obligasi I/2008 seri B senilai Rp.280 miliar yang jatuh tempo pada 11 Maret 2013. PT Pemeringkat Efek Indonesia (Pefindo) sebelumnya telah menurunkan peringkat obligasi lini usaha properti Grup Bakrie itu dari 'idB' menjadi 'idCCC' karena perseroan pengalokasian dana pelunasan obligasi I/2008 seri B masih belum tercukupi. Selain menurunkan peringkat, Pefindo juga masih menempatkan peringkat utang emiten yang saham dan obligasinya berkode ELTY tersebut pada posisi pengawasan kredit berimplikasi negatif (kompas.com, 2013). Kasus gagal bayar juga terjadi pada tahun 2010 dimana Obligasi I PT. Mobile8 Telecom Tbk sebesar Rp.675 miliar berkali-kali gagal dalam memenuhi kewajiban menyediakan dana untuk pembayaran bunga. Atas kegagalan tersebut, Bursa Efek Indonesia telah memberikan sanksi penghentian sementara perdagangan efek PT. Mobile-8 Telecom Tbk. Peringkat obligasi ini juga telah diturunkan menjadi “idD” oleh lembaga pemeringkat PEFINDO.

Di Indonesia terdapat beberapa lembaga pemeringkat yaitu PT Pemeringkat Efek Indonesia (PEFINDO), PT ICRA Indonesia dan Fitch Ratings Indonesia. Lembaga pemeringkat melakukan kajian secara periodik hingga obligasi tersebut jatuh tempo. Lembaga pemeringkat dalam menentukan peringkat suatu efek bersifat utang mendasarkan pada berbagai pertimbangan peringkat (rating rationale) baik yang bersifat mendukung (supporting factors) maupun faktor yang membatasi (offsetting factors). Perubahan outlook atas peringkat obligasi berpotensi mengalami kenaikan atau penurunan peringkat di masa mendatang. Perubahan outlook atau bahkan peringkat suatu obligasi dapat menunjukan kondisi kinerja perusahaan dan indikator 
keuangan. Hal ini dapat menjadi rujukan bagi investor untuk mengambil keputusan mengikuti perubahan peringkat obligasi.

Definisi peringkat dari 3 lembaga pemeringkat di atas menurut Wijayanto (2015) adalah sebagai berikut:

\begin{tabular}{|c|c|c|c|}
\hline $\begin{array}{c}\text { Fitch } \\
\text { Indonesia }\end{array}$ & $\begin{array}{c}\text { ICRA } \\
\text { Indonesia }\end{array}$ & PEFINDO & Keterangan \\
\hline AAA(idn) & [ldr]AAA & Id $A A A$ & Prime, maximum safety \\
\hline $\begin{array}{l}\text { AA+(idn) } \\
\text { s.d. AA- } \\
\text { (idn) }\end{array}$ & $\begin{array}{l}{[\mathrm{ldr}] \mathrm{AA}+} \\
\text { s.d. }[\mathrm{ldr}] \mathrm{AA}-\end{array}$ & $\begin{array}{l}\operatorname{ld} A A+s . d \\
\operatorname{ld} A A-\end{array}$ & Very high grade, high quality \\
\hline $\begin{array}{l}\text { A+(idn) s.d. } \\
\text { A-(idn) }\end{array}$ & $\begin{array}{l}{[\operatorname{ldr}] A+\text { s.d. }} \\
\text { [ldr]A- }\end{array}$ & ${ }_{1 d} A+$ s.d. ${ }_{1 d} A-$ & Upper medium grade \\
\hline $\begin{array}{l}\text { BBB+(idn) } \\
\text { s.d. BBB- } \\
\text { (idn) }\end{array}$ & $\begin{array}{l}\text { [ldr]BBB+ } \\
\text { s.d. } \\
\text { [ldr]BBB- }\end{array}$ & $\begin{array}{l}\text { Id BBB+s.d. } \\
\text { Id BBB- }\end{array}$ & Lower medium grade \\
\hline $\begin{array}{l}\text { BB+(idn) } \\
\text { s.d. BB- } \\
\text { (idn) }\end{array}$ & $\begin{array}{l}{[\mathrm{ldr}] \mathrm{BB}+} \\
\text { s.d. [ldr]BB- }\end{array}$ & $\begin{array}{l}\text { IdBB+ s.d. } \\
{ }_{\text {Id BB- }} \text { BB }\end{array}$ & Low grade, speculative \\
\hline $\begin{array}{l}\text { B+(idn) s.d. } \\
\text { B-(idn) }\end{array}$ & $\begin{array}{l}{[\mathrm{ldr}] \mathrm{B}+\mathrm{s} . \mathrm{d}} \\
\text { [ldr]B- }\end{array}$ & ${ }_{1 d} \mathrm{~B}+$ s.d. ${ }_{1 d} \mathrm{~B}-$ & Highly speculative \\
\hline $\begin{array}{l}\text { Kurang dari } \\
\text { B-(idn) }\end{array}$ & $\begin{array}{l}\text { Kurang dari } \\
\text { [ldr]B- }\end{array}$ & $\begin{array}{l}\text { Kurang dari } \\
\text { ld B- }\end{array}$ & $\begin{array}{l}\text { Predominantly Speculative: Substantial Risk or in } \\
\text { Default }\end{array}$ \\
\hline
\end{tabular}

Peringkat obligasi memiliki arti penting bagi investor dan perusahaan karena menjadi indikator dari risiko gagal bayar. Peringkat memiliki pengaruh langsung yang dapat diukur pada tingkat bunga obligasi dan biaya utang perusahaan. Risiko gagal bayar tersebut menjadi risiko terbesar yang dihadapi calon investor dimana perusahaan tidak mampu membayar bunga dan melunasi pokok kewajiban selama umur obligasi. Pada penelitian ini faktor yang digunakan untuk memprediksi peringkat obligasi adalah faktor akuntansi dan faktor non akuntansi sebagai berikut:

Rasio leverage merupakan rasio yang digunakan untuk mengukur sejauh mana aktiva perusahaan dibiayai dengan utang (Kasmir, 2015). Artinya besarnya jumlah utang yang digunakan perusahaan untuk membiaya kegiatan usahanya dibandingkan dengan menggunakan modal sendiri. Pecking Order Theory menjelaskan sumber dana perusahaan sesuai dengan hirarki yang paling 
disukai yaitu investasi akan dibiayai menggunakan dana internal terlebih dahulu (laba yang ditahan), kemudian baru diikuti oleh penerbitan utang baru, dan akhirnya dengan penerbitan ekuitas baru (Husnan dan Pudjiastuti, 2015). Manfaat penggunaan utang berasal dari penghematan pajak karena sifat tax deductibility of interest payment (pembayaran bunga bisa dipakai untuk mengurangi beban pajak). Dalam memenuhi kebutuhan pendanaan dari utang, sejauh manfaat lebih besar, utang akan ditambah, sebaliknya bila pengorbanan karena menggunakan utang sudah lebih besar, maka utang tidak boleh lagi ditambah (Husnan dan Pudjiastuti, 2015).

Rasio likuiditas merupakan rasio yang menggambarkan kemampuan perusahaan dalam memenuhi kewajiban jangka pendek (Fred Weston dalam Kasmir, 2015). Fungsi lain rasio likuiditas adalah untuk mengukur atau menunjuk kemampuan perusahaan dalam membayar kewajibannya yang jatuh tempo, baik kewajiban kepada pihak luar perusahaan maupun pihak di dalam perusahaan. Dengan kata lain rasio untuk mengukur kemampuan perusahaan membiayai dan memenuhi kewajiban pada saat ditagih. Menurut Kasmir (2015) menyatakan bahwa apabila perusahaan mampu untuk memenuhi kewajiban jangka pendek dikatakan bahwa perusahaan dalam keadaan likuid. Disebut likuid karena jumlah aktiva lancar yang dimiliki perusahaan lebih besar daripada jumlah kewajiban jangka pendek. Kemampuan perusahaan dalam memenuhi kewajiban jangka pendek mencerminkan kemampuan perusahaan memenuhi kewajiban jangka panjang secara tidak langsung. Oleh sebab itu, peringkat obligasi akan dapat dipengaruhi oleh tingkat likuiditas perusahaan.

Rasio profitabilitas memberikan ukuran tingkat efektifitas manajemen suatu perusahaan yang ditunjukan dari laba yang dihasilkan dari penjualan dan laba investasi (Kasmir, 2015). Dengan tingkat laba yang maksimal perusahaan dapat berbuat banyak bagi kesejahteraan pemilik, karyawan maupun investor. Dengan demikian perusahaan mempunyai indikasi keuangan yang sehat dan memiliki kemampuan memenuhi kewajiban baik jangka pendek maupun jangka panjang. Dengan adanya kondisi tersebut maka obligasi akan memiliki peringkat yang tinggi karena keuntungan 
perusahaan dapat digunakan untuk memenuhi keawajiban obligasi. Dengan kata lain dapat dikatakan bahwa profitabilitas yang tinggi akan menurunkan kemungkinan perusahaan mengalami gagal bayar.

Rasio aktivitas digunakan untuk mengukur tingkat efektivitas perusahaan dalam memanfaatkan aktiva yang dimilikinya. Rasio ini menilai kemampuan perusahan dalam melaksanakan aktivitas sehari-hari. Tingkat efektivitas dalam menggunakan aktiva perusahaan dapat mengurangi biaya dan meningkatkan laba yang diperoleh perusahaan. Sehingga pada akhirnya dengan kemampuan tersebut maka perusahaan akan mampu dalam memenuhi kewajiban yang dimilikinya termasuk obligasi. Kemampuan perusahaan memenuhi kewajibannya akan membantu meningkatkan peringkat obligasi perusahaan tersebut. Rasio aktivitas yang diproksikan dengan Total Assets Turnover (TAT) yang tinggi menunjukan bahwa perusahaan efektif dalam menggunaan aktiva yang dimiliki untuk menghasilkan pendapatan.

Umur obligasi atau jatuh tempo (maturity) adalah tanggal dimana penerbit obligasi berkewajiban melakuan pelunasan pembayaran pokok atau nilai nominal obligasi yang telah diterbitkan. Umur obligasi bermacam-macam dari mulai 1 tahun sampai diatas 5 tahun. Risiko obligasi yang akan segera jatuh tempo akan lebih mudah untuk diprediksi, sehingga mengurangi risikonya dibandingkan obligasi yang masih memiliki periode jatuh tempo lebih panjang. Secara umum, semakin panjang jatuh tempo suatu obligasi, semakin tinggi kupon atau bunganya (Wijayanto, 2015). Menurut Sitorus (2015), secara umum, semakin pendek umur jatuh tempo suatu surat utang, semakin kecil risiko default dan semakin likuid efek yang bersangkutan sehingga peringkatnya cenderung akan naik. Dalam praktiknya, penilaian suatu efek surat utang yang akan segera jatuh tempo para pelaku pasar cenderung tidak memperhatikan peringkat karena risiko gagal bayar cenderung semakin kecil. 


\section{METODOLOGI PENELITIAN}

Penelitian ini menggunakan regresi logistik dalam melakukan pengujian model dan hipotesis. Regresi logistik ini dilakukan guna menguji apakah probabilitas terjadinya variabel terikat yang dikotomi dimana dianggap hanya mempunyai dua nilai yang mungkin yaitu 0 dan 1, dapat diprediksi dengan satu atau lebih variabel bebasnya. Dalam melakukan analisis logistik tidak perlu lagi menggunakan uji normalitas data pada variabel bebasnya (Ghozali, 2013), dikarenakan variable terikatnya merupakan variabel yang dikotomi (0 dan 1).

Pada penelitian ini persamaan regresi logistik adalah sebagai berikut:

$$
\operatorname{Ln} \frac{p}{1-p}=\beta_{0}+\beta_{1} \mathrm{DER}+\beta_{2} \mathrm{CR}+\beta_{3} \mathrm{ROA}+\beta_{4} \mathrm{TAT}+\beta_{5} \mathrm{MAT}+\varepsilon
$$

Keterangan :

$\begin{array}{ll}\operatorname{Ln} \frac{p}{1-p}=\mathrm{Y} & : \text { Peringkat obligasi }(\mathrm{Y}=1, \text { jika peringkat obligasi masuk } \\ & \text { kategori investment grade dan } \mathrm{Y}=0 \text { jika peringkat obligasi } \\ & \text { masuk kategori non-investment grade }) \\ \beta_{0} & : \text { Konstan } \\ \text { DER } & : \text { Rasio Leverage } \\ \text { CR } & : \text { Rasio Likuiditas } \\ \text { ROA } & : \text { Rasio Profitabilitas } \\ \text { TAT } & : \text { Rasio Aktifitas } \\ \text { MAT } & : \text { Umur Obligasi (0 jika obligasi berumur 1 sampai dengan 5 } \\ & \text { tahun, 1 jika obligasi berumur lebih dari } 5 \text { tahun) } \\ \varepsilon & : \text { Error }, \text { kesalahan baku }\end{array}$

Penelitian ini merupakan penelitian hubungan kausal (causal effect), yaitu penelitian yang dirancang untuk menguji pengaruh suatu variabel terhadap variabel lain. Penelitian ini menggunakan pendekatan kuantitatif yang merupakan penekanan pada pengujian teori melalui pengukuran variabel penelitian dengan angka dan melakukan analisis data dengan prosedur statistik.

Dalam penelitian ini, metode tersebut digunakan untuk menguji kembali variabel independen yang berupa leverage yang diukur dengan dengan Debt to 
Equity Ratio (DER), likuiditas yang diukur dengan Current Ratio (CR), Profitabilitas diukur dengan Return on Assets (ROA) dan aktivitas diukur dengan Total Asset Turnover (TAT) serta umur obligasi terhadap variable dependen berupa peringkat obligasi pada perusahaan non keuangan yang listing di Bursa Efek Indonesia tahun 2010-2014. Karena keterbatasan data dalam penelitian maka peringkat obligasi dibagi dalam dua kategori yaitu kategori investment grade dengan klasifikasi 1 dan non-investment grade dengan klasifikasi 0.

Hipotesa penelitian ini adalah sebagai berikut:

$\mathrm{H}_{1}$ : Leverage berpengaruh negatif terhadap peringkat obligasi perusahaan.

$\mathrm{H}_{2}$ : Likuiditas berpengaruh positif terhadap peringkat obligasi perusahaan.

$\mathrm{H}_{3}$ : Profitabilitas berpengaruh positif terhadap peringkat obligasi perusahaan.

$\mathrm{H}_{4}$ : Rasio aktivitas berpengaruh positif terhadap peringkat obligasi perusahaan.

$\mathrm{H}_{5}$ : Umur Obligasi berpengaruh positif terhadap peringkat obligasi perusahaan.

\section{HASIL PENELITIAN DAN PEMBAHASAN}

Berdasarkan pada kriteria sampel yang ditetapkan, maka diperoleh sebanyak 47 perusahaan dan dikelompokkan menjadi dua kategori berdasarkan peringkatnya yaitu investment grade dan non-investment grade. Dari 47 perusahaan yang diamati mulai dari tahun 2010 sampai dengan tahun 2014 diketahui bahwa terdapat 38 perusahaan yang masuk ke dalam kategori investment grade dan 9 perusahaan yang masuk ke dalam kategori non-investment grade.

Berikutnya statistik deskriptif yang berfungsi untuk mengetahui karakteristik sampel yang digunakan dalam penelitian. Tabel 1 menyajikan hasil statistik deskriptif untuk variabel independen dalam penelitian.

\section{Tabel 1}

Descriptive Statistics

\begin{tabular}{|c|c|c|c|c|c|}
\hline & $\mathrm{N}$ & Minimum & Maximum & Mean & Std. Deviation \\
\hline
\end{tabular}




\begin{tabular}{|l|r|r|r|r|r|}
\hline DER & 47 & -5.24 & 5.15 & 1.2300 & 1.60861 \\
CR & 47 & .22 & 4.10 & 1.4353 & .71674 \\
ROA & 47 & .00 & 18.96 & 6.5104 & 4.33973 \\
TAT & 47 & .12 & 3.24 & .8347 & .68390 \\
MAT & 47 & .00 & 1.00 & .1702 & .37988 \\
Valid N (listwise) & 47 & & & & \\
\hline
\end{tabular}

Nilai rata-rata DER adalah 1.230 dengan standar deviasi 1.60861, yang berarti bahwa standar deviasi lebih besar daripada nilai rata-ratanya. Hal ini menunjukkan bahwa nilai rata-rata DER tidak dapat merepresentasikan keseluruhan data karena DER mempunyai sebaran besar dan simpangan data dapat dikatakan kurang baik.

Nilai rata-rata CR adalah 1.4353 dengan standar deviasi 0.71674, yang berarti bahwa standar deviasi lebih kecil daripada nilai rata-ratanya. Hal ini menunjukkan bahwa nilai rata-rata CR dapat merepresentasikan keseluruhan data karena CR mempunyai sebaran kecil dan simpangan data dapat dikatakan baik.

Nilai rata-rata ROA adalah 6.5104 dengan standar deviasi 4.33973, yang berati bahwa standar deviasi lebih kecil daripada nilai rata-ratanya. Hal ini menunjukkan bahwa nilai rata-rata ROA dapat merepresentasikan keseluruhan data karena ROA mempunyai sebaran kecil dan simpangan data yang baik.

Nilai rata-rata TAT adalah 0.8347 dengan standar deviasi 0.6839, yang berarti bahwa standar deviasi lebih kecil daripada nilai rata-ratanya. Hal ini menunjukkan bahwa nilai rata-rata TAT dapat merepresentasikan keseluruhan data karena TAT mempunyai sebaran kecil dan simpangan data dapat dikatakan baik.

Nilai rata-rata MAT adalah 0.1702 dengan standar deviasi 0.37988 , yang berati bahwa standar deviasi lebih besar daripada nilai rata-ratanya. Hal ini menunjukkan bahwa 
nilai rata-rata MAT tidak dapat merepresentasikan keseluruhan data karena MAT mempunyai sebaran besar dan simpangan data yang kurang baik.

Tahap selanjutnya adalah menilai keseluruhan model fit (overall model fit). Pengujian ini dilakukan dengan menggunakan Hosmer and Lemeshow's Goodness of Fit Test. Hasil yang diperoleh dari data yang telah diolah dengan program SPSS 23 adalah sebagai berikut:

Tabel 2

Hosmer and Lemeshow Test

\begin{tabular}{|l|r|r|r|}
\hline Step & \multicolumn{1}{|c|}{ Chi-square } & df & \multicolumn{2}{|c|}{ Sig. } \\
\hline 1 & 8.525 & 7 & .289 \\
\hline
\end{tabular}

Pengujian ini untuk menguji hiopotesis nol bahwa data empiris cocok atau sesuai model (tidak ada perbedaan antara model dengan data sehingga model dapat dikatakan fit). Jika nilai Hosmer and Lemeshow's Goodness of Fit Test lebih kecil atau sama dengan $\alpha$ sebesar 0,05 , maka hipotesis nol ditolak yang berarti ada perbedaan signifikan antara model dengan nilai observasinya sehingga Goodnes fit model tidak baik karena model tidak dapat memprediksi nilai observasinya. Jika nilai statistik Hosmer and Lemeshow's Goodness of Fit Test lebih besar daripada $\alpha$ sebesar 0,05, maka hipotesis nol tidak dapat ditolak yang berarti model mampu memprediksi nilai observasinya atau dapat dikatakan model dapat diterima karena cocok dengan data observasinya. Dilihat dari tabel 2 nilai Hosmer and Lemeshow Test adalah sebesar 8.525 dengan probabilitas signifikansi 0,289 yang nilainya jauh lebih besar dari 0,05. Dengan demikian maka dapat disimpulkan bahwa model dapat diterima.

Untuk mengetahui variabilitas variabel dependen yang dapat dijelaskan oleh variabel independen dapat diinterprestasikan dengan nilai Nagelkerke $R$ Square, yang merupakan modifikasi dari koefisien Cox dan Snell untuk memastikan bahwa nilainya bervariasi dari 0 sampai 1 . Hal ini dilakukan dengan 
cara membagi Cox dan Snell $R$ Square dengan nilai maksimumnya. Dari sini akan diketahui seberapa besar variabel dependen mampu dijelaskan oleh variabel independen.

Tabel 3

Model Summary

\begin{tabular}{|l|r|r|r|}
\hline Step & \multicolumn{1}{|c|}{-2 Log likelihood } & $\begin{array}{c}\text { Cox \& Snell R } \\
\text { Square }\end{array}$ & \multicolumn{2}{|c|}{$\begin{array}{c}\text { Nagelkerke R } \\
\text { Square }\end{array}$} \\
\hline 1 & $22.532^{\mathrm{a}}$ & .392 & .629 \\
\hline
\end{tabular}

a. Estimation terminated at iteration number 7 because parameter estimates changed by less than .001 .

Berdasarkan hasil output SPSS nilai Cox dan Snell $R$ Square sebesar 0,392 dan nilai Nagelkerke $R$ Square adalah 0,629 yang berarti variabilitas variabel dependen yang dapat dijelaskan oleh variabilitas variabel independent sebesar 62,90\%. Sedangkan sisanya sebesar 100\%-62,9\%=37,1\% dijelaskan oleh faktor lain di luar model.

Variabel peringkat obligasi yang mampu dijelaskan oleh variabel independen berupa leverage, likuiditas, profitabilitas, aktivitas dan umur obligasi hanya salah satu dari faktor-faktor yang mampu memengaruhi peringkat obligasi. Faktor lain yang berpengaruh terhadap peringkat obligasi antara lain adalah kinerja industri (persaingan industri, prospek dan pangsa pasar, adanya ketersediaan bahan baku, struktur industri yang kuat, pengaruh kebijakan pemerintah dan kebijakan ekonomi lainnya), kinerja keuangan (kualitas aset, rasio profitabilitas, pengelolaan aset dan pasiva, rasio kecukupan modal, tingkat pengelolaan utang, dan rasio kecukupan pembayaran bunga) dan kinerja nonkeuangan (aspek manajemen, reputasi perusahaan, serta perjanjian indenture) (Raharjo, 2003). 
Tabel 4

Variables in the Equation

\begin{tabular}{|c|c|c|c|c|c|c|c|c|c|}
\hline & \multirow[b]{2}{*}{ B } & \multirow[b]{2}{*}{ S.E. } & \multirow[b]{2}{*}{ Wald } & \multirow[b]{2}{*}{$\mathrm{df}$} & \multirow[b]{2}{*}{ Sig. } & \multirow[b]{2}{*}{$\operatorname{Exp}(B)$} & \multicolumn{2}{|c|}{$\begin{array}{c}\text { 95\% C.I.for } \\
\text { EXP(B) }\end{array}$} \\
\hline & & & & & & & & Lower & Upper \\
\hline \multirow{6}{*}{$\begin{array}{l}\text { Step } \\
1^{\text {a }}\end{array}$} & DER & .875 & .579 & 2.281 & 1 & .131 & 2.398 & .771 & 7.463 \\
\hline & $\mathrm{CR}$ & -.595 & .800 & .554 & 1 & .457 & .551 & .115 & 2.645 \\
\hline & ROA & .703 & .288 & 5.957 & 1 & .015 & 2.020 & 1.149 & 3.554 \\
\hline & TAT & .481 & 1.206 & .159 & 1 & .690 & 1.618 & .152 & 17.205 \\
\hline & $\operatorname{MAT}(1)$ & .282 & 1.469 & .037 & 1 & .848 & 1.326 & .074 & 23.624 \\
\hline & Constant & -2.225 & 1.608 & 1.914 & 1 & 167 & .108 & & \\
\hline
\end{tabular}

a. Variable(s) entered on step 1: DER, CR, ROA, TAT, MAT.

Persamaan regresi logistik yang diperoleh dari table 4 di atas, adalah sebagai berikut:

$\operatorname{Ln} \frac{p}{1-p}=-2.225+0.875 \mathrm{DER}-0.595 \mathrm{CR}+0.703 \mathrm{ROA}+0.481 \mathrm{TAT}+0.282 \mathrm{MAT}$

Hipotesis 1 menyatakan bahwa leverage perusahaan berpengaruh negatif terhadap peringkat obligasi. Hasil pengujian regresi menunjukkan bahwa leverage perusahaan yang diproksi dengan DER (Debt to Equity Ratio) memiliki nilai koefisien positif sebesar 0,875 dengan tingkat signifikansi 0,131 dan nilai statistik wald sebesar 2,281. Nilai signifikansi ini lebih besar dari 0,05. Artinya dapat disimpulkan bahwa $\mathrm{H}_{1}$ tidak berhasil didukung, sehingga hipotesis 1 ditolak.. Hasil penelitian ini menunjukkan bahwa DER tidak berpengaruh terhadap prediksi peringkat obligasi. Hal ini sesuai dengan penelitian Magreta dan Nurmayanti (2009), penelitian Hadianto dan Wijaya (2010) dan penelitian Yuliana, dkk (2011) yang menyatakan bahwa leverage yang diproksikan dengan DER (Debt to Equity Ratio) tidak berpengaruh terhadap peringkat obligasi. Perusahaan yang sebagian besar asetnya didanai dengan utang memiliki risiko gagal bayar yang besar, namun disatu sisi utang yang dikelola dengan baik dapat memberi kontribusi 
terhadap pendapatan perusahaan dan utang juga dapat mengurangi beban pajak karena pembayaran bunga bisa mengurangi beban pajak perusahaan sehingga akan meningkatkan laba perusahaan. Hal ini akan membuat perusahaan memliki kemampuan memenuhi kewajibannya hingga akhirnya akan menaikan peringkat obligasi perusahaan.

Hipotesis 2 menyatakan bahwa likuiditas perusahaan berpengaruh positif terhadap peringkat obligasi. Hasil pengujian regresi menunjukkan bahwa likuiditas perusahaan yang diproksi dengan CR (Current Ratio) memiliki nilai koefisien negatif sebesar -0,595 dengan tingkat signifikansi 0,457 dan nilai statistik wald sebesar 0,554. Nilai signifikansi ini jauh lebih besar dari 0,05. Artinya dapat disimpulkan bahwa $\mathrm{H}_{2}$ tidak berhasil didukung, sehingga hipotesis 2 ditolak. Hasil penelitian ini menunjukkan bahwa CR tidak berpengaruh terhadap peringkat obligasi perusahaan. Hal ini sejalan dengan penelitian Hadianto (2010) dan penelitian Widiyastuti (2011) bahwa likuiditas tidak berpengaruh terhadap kemungkinan penentuan peringkat obligasi. Tidak berpengaruhnya ini terjadi bisa karena aset lancar perusahaan yang terlalu besar, dimana hal ini tidak menjamin bahwa aset lancar tersebut dapat digunakan untuk membayar kewajiban perusahaan yang jatuh tempo. Seperti di perusahaan manufaktur salah satu aset lancar dapat berupa persediaan yang berupa bahan baku, persediaan bahan setengah jadi. Persediaan seperti ini merupakan aset lancar yang tidak likuid karena semakin panjangnya tahapan yang dilalui untuk menjadi kas. Hal seperti ini yang dapat menyebabkan aset lancar menjadi lebih besar daripada utang lancar, namun tidak menjamin perusahaan dapat memenuhi kewajibannya yang akan jatuh tempo.

Hipotesis 3 menyatakan bahwa profitabilitas perusahaan berpengaruh positif terhadap peringkat obligasi. Hasil pengujian regresi menunjukkan bahwa profitabilitas perusahaan yang diproksi dengan ROA (Return on Asset) memiliki nilai koefisien positif sebesar 0,703 dengan tingkat signifikansi 0,015 dan nilai statistik wald sebesar 5,957. Nilai signifikansi ini lebih kecil dari 0,05. Artinya dapat disimpulkan bahwa $\mathrm{H}_{3}$ berhasil didukung, sehingga hipotesis 3 diterima. Hasil penelitian ini menunjukkan bahwa profitabilitas perusahaan berpengaruh 
terhadap peringkat obligasi perusahaan. Hasil penelitian ini sesuai dengan hasil penelitian Amalia (2013), penelitian Yuliana, dkk (2011) dan penelitian Hadianto dan Wijaya (2010) yang menyatakan bahwa ROA berpengaruh terhadap peringkat obligasi. Dengan demikian maka profitabilitas memberi pengaruh pada tinggi rendahnya peringkat obligasi yang diterbitkan perusahaan. Dengan ROA yang semakin tinggi maka peringkat obligasi perusahaan akan semakin tinggi pula. Sehingga perusahaan dengan profitabilitas tinggi mempunya kecenderungan akan mampu memenuhi kewajiban membayar terhadap pokok dan bunga obligasi yang diterbitkannya. Dengan demikian akan memberi pengaruh yang positif terhadap peringkat obligasi perusahaan dalam memperoleh peringkat obligasi dengan kategori layak investasi dibandingkan dengan perusahaan yang profitabilitasnya rendah.

Hipotesis 4 menyatakan bahwa aktivitas perusahaan berpengaruh positif terhadap peringkat obligasi. Hasil pengujian regresi menunjukkan bahwa aktivitas perusahaan yang diproksi dengan TAT (Total Assets Turnover) memiliki nilai koefisien positif sebesar 0,481 dengan tingkat signifikansi 0,690 dan nilai statistik wald sebesar 0,159. Nilai signifikansi ini jauh lebih besar dari 0,05. Artinya dapat disimpulkan bahwa $\mathrm{H}_{4}$ tidak berhasil didukung, sehingga hipotesis 4 ditolak. Hasil penelitian ini menunjukkan bahwa aktivitas perusahaan tidak berpengaruh terhadap peringkat obligasi perusahaan. Hasil penelitian ini konsisten dengan hasil penelitian Yuliana, dkk (2011) yang menyatakan bahwa TAT tidak berpengaruh signifikan terhadap peringkat obligasi. Kondisi ini terjadi karena perusahaan yang memiliki pendapatan tinggi belum tentu akan memiliki laba yang tinggi pula. Margin laba yang tinggi yang lebih memberi pengaruh karena membuktikan bahwa perusahaan efektif dalam mengelola sumber daya perusahaan sehingga mampu meminimalkan biaya atau pengeluaran.

Hipotesis 5 menyatakan bahwa umur obligasi perusahaan berpengaruh positif terhadap peringkat obligasi. Hasil pengujian regresi menunjukkan bahwa umur obligasi perusahaan memiliki nilai koefisien positif sebesar 0,282 dengan tingkat signifikansi 0,848 dan nilai statistik wald sebesar 0,037. Nilai signifikansi ini lebih besar dari 0,05. Artinya dapat disimpulkan bahwa $\mathrm{H}_{5}$ tidak berhasil 
didukung, sehingga hipotesis 5 ditolak. Hasil penelitian ini menunjukkan bahwa umur obligasi perusahaan tidak berpengaruh terhadap peringkat obligasi perusahaan. Hasil penelitian ini sejalan dengan hasil penelitian Ma'arij (2014) dan penelitian Ikhsan (2012), yang menyatakan tidak ada pengaruh signifikan umur obligasi terhadap peringkat obligasi. Hal ini terjadi karena pada umumnya analisis menggunakan regresi logistik, di mana variabel bebasnya tidak menggunakan variabel dummy sehingga menyebabkan hasilnya menjadi tidak signifikan.

\section{KESIMPULAN}

Beberapa kesimpulan yang dapat diperoleh berdasarkan hasil analisis terhadap seluruh hipotesis adalah sebagai berikut:

1. Leverage (DER) berpengaruh positif dan tidak signifikan terhadap prediksi peringkat obligasi perusahaan yang terdaftar di Bursa Efek Indonesia tahun $2010-2014$.

2. Likuiditas (CR) berpengaruh negatif dan tidak signifikan terhadap prediksi peringkat obligasi perusahaan yang terdaftar di Bursa Efek Indonesia tahun $2010-2014$.

3. Profitabilitas (ROA) berpengaruh positif dan signifikan terhadap prediksi peringkat obligasi perusahaan yang terdaftar di Bursa Efek Indonesia tahun $2010-2014$.

4. Aktiviitas (TAT) berpengaruh positif dan tidak signifikan terhadap prediksi peringkat obligasi perusahaan yang terdaftar di Bursa Efek Indonesia tahun $2010-2014$.

5. Umur obligasi (MAT) berpengaruh negatif dan tidak signifikan terhadap prediksi peringkat obligasi perusahaan yang terdaftar di Bursa Efek Indonesia tahun $2010-2014$.

Analisis terhadap variable leverage (debt to equity ratio), likuiditas (current ratio), aktifitas (return on assets) dan variable umur obligasi menunjukan pengaruh yang tidak signifikan. Hal ini terjadi karena tidak terdapatnya perbedaan 
variabel-variabel independen tersebut antara perusahaan penerbit obligasi yang memiliki peringkat investment grade dengan yang non-investment grade.

\section{SARAN}

Saran yang dapat diberikan bagi pihak yang ingin melakukan penelitian selanjutnya adalah :

1. Dalam penelitian ini menggunakan lima variabel independen dalam memprediksi peringkat obligasi. Dan hasil koefisien determinasi juga menunjukan bahwa variabel tersebut hanya 62,9\% dapat menjelaskan variabel dependen. Oleh sebab itu penelitian selanjutnya disarankan untuk menggunakan variabel lain baik variabel keuangan maupun non-keuangan. Serta jumlah variabel juga dapat ditambah sehingga hasil yang diperoleh dapat lebih baik dan variabel-variabel yang mempunyai pengaruh terhadap peringkat obligasi dapat terakomodir dalam penelitian selanjutnya.

2. Keterbatasan pada penelitian ini juga pada periode pengamatan yaitu dari tahun 2010 - 2014. Bagi penelitian selanjutnya dapat memperpanjang periode pengamatan sehingga data yang diperoleh untuk penelitian dapat lebih representatif. Serta dapat menggunakan kategori atau sektor lain untuk sampel perusahaan yang dipilih.

\section{DAFTAR PUSTAKA}

Almilia, Luciana Spica \& Devi, Vieka. (2007). Faktor-faktor yang Mempengaruhi Prediksi Peringkat Obligasi pada Perusahaan Manufaktur yang Terdaftar di Bursa Efek Jakarta. Proceeding Seminar Nasional Manajemen SMART. Amalia, Ninik. (2013). Pemeringkatan Obligasi PT Pefindo: Berdasarkan Informasi Keuangan. Accounting Analysis Journal 2 (2) (2013). Andry, Wydia. (2005). Analisis Faktor-Faktor Yang Mempengaruhi Prediksi

Peringkat Obligasi. Buletin Ekonomi Moneter dan Perbankan. Hal 242-262. Brigham, Eugene F dan Joel F. Houston. (2010). Dasar Dasar Manajemen Keuangan, Edisi 11. Jakarta: Salemba Empat. Gudono. (2015). Analisis Data Multivariat, Edisi 4. Yogyakarta: BPFE. 
Ghozali, Imam (2013). Aplikasi Analisis Multivariate dengan Program IBM SPSS 21, Edisi 7. Semarang: Badan Penerbit Universitas Diponegoro.

Hadianto, Bram dan Wijaya, M. Sienly Veronica. (2010). Prediksi Kebijakan Utang, Profitabilitas, Likuiditas, Ukuran, dan Status Perusahaan Terhadap Kemungkinan Penentuan Peringkat Obligasi: Studi Empirik Pada Perusahaan Yang Menerbitkan Obligasi Di Bursa Efek Indonesia, Jurnal Manajemen Teori dan Terapan. Tahun 3, No.3, Desember 2010.

Hermanto, Bambang dan Agung, Mulyo., (2015). Analisa Laporan Keuangan, Cetakan ke-4. Jakarta: Lentera Ilmu Cendekia.

Husnan, Suad dan Pudjiastuti, Enny. (2015). Dasar-Dasar Manajemen Keuangan, Edisi Ketujuh. Yogyakarta: UPP STIM YKPN.

Ikhsan, Adhisyahfitri Evalina; Yahya, M Nur dan Saidaturrahmi. (2012).

Peringkat Obligasi dan Faktor Yang Mempengaruhinya. Pekbis Jurnal Vol. 4 No. 2 Juli 2012: 115-123.

Kasmir. (2015). Analisis Laporan Keuangan, Edisi 8. Jakarta: PT RajaGrafindo Persada.

Ma'arij, Arinurtry; Zulbahridar; Al Azhar A. (2014). Analisis Faktor Akuntansi dan Non Akuntansi Yang Mempengaruhi Prediksi Peringkat Obligasi Pada Perusahaan Non Keuangan Yang Terdaftar di BEI dan Diperingkat Oleh PEFINDO Periode 2009-2013. Jurnal FEKON Vol. 1 No. 2 Oktober 2014. Rahardjo, Sapto. (2003). Panduan Investasi Obligasi. Jakarta: PT Gramedia Pustaka Utama.

Raharja dan Sari, Mayla Pramono. (2008). Kemampuan Rasio Keuangan Dalam Memprediksi Peringkat Obligasi (PT Kasnic Credit Rating). Jurnal Maksi Vol. 8 No. 2 Agustus 2008: 212-232.

Satoto, Shinta Heru. (2011). Analisis Faktor-Faktor yang Mempengaruhi Bond Rating. Karisma. Vol. 5 (1): 104-115.

Sejati, Grace Putri. (2010). Analisis Faktor Akuntansi dan Non Akuntansi Dalam Memprediksi Peringkat Obligasi Perusahaan Manufaktur. Bisnis dan Birokrasi, Jurnal Ilmu Administrasi dan Organisasi Jan-Apr 2010 hal. 70-78. 
Septyawanti, Hilda Indria. (2013). Faktor-Faktor Yang Mempengaruhi Peringkat

Obligasi Perusahaan. Accounting Analysis Journal 2 (3) (2013).

Sitorus, Tarmiden., (2015). Pasar Obligasi Indonesia: Teori dan Praktek. Jakarta:

PT RajaGrafindo Persada.

Sjahrial, Dermawan. (2012). Pengantar Manajemen Keuangan, Edisi 4. Jakarta:

Mitra Wacana Media.

Susilowati, Luky dan Sumartono. (2010). Memprediksi Tingkat Obligasi

Perusahaan Manufaktur yang Listing di BEI. Jurnal Mitra Ekonomi dan

Manajemen Bisnis, Volume 1 No. 2 Oktober 2010, 163-175.

Widiyastuti, Tetty, Djumahir dan Khusniyah, Nur (2014). Faktor-Faktor Yang

Berpengaruh Terhadap Peringkat Obligasi (Studi pada perusahaan Manufaktur

yang terdaftar di BEI). Jurnal Aplikasi Manajemen Volume 12 Nomor 2 Juni 2014.

Werastuti, Desak Nyoman Sri. (2015). Analisis Prediksi Peringkat Obligasi

Perusahaan Dengan Pendekatan Faktor Keuangan dan Non Keuangan. Jurnal

Dinamika Akuntansi Vol. 7 No. 1 Maret 2015.

Wijayanti, Indah dan Priyadi, Maswar Patuh. (2014). Faktor-Faktor Yang

Mempengaruhi Peringkat Obligasi. Jurnal Ilmu dan Riset Akuntansi dan

Bisnis Vol. 3 No. 32014.

Wijayanto, Setyo. (2015), Strategi Jitu Investasi Obligasi Korporasi: Sudut

Pandang Investasi dari Seorang Analis. Jakarta: PT Elex Media Komputindo.

Yuliana, Rika; Prabowo, Muhammad Agung; dan Arifin, Taufik. (2011). Analisis

Faktor-Faktor Yang Mempengaruhi Prediksi Peringkat Obligasi Pada

Perusahaan Keuangan Yang Terdaftar Di Bursa Efek Indonesia. Simposium

Nasional Akuntansi XIV Aceh.

Zurohtun. (2013). Prediksi Peringkat Obligasi Dengan Persistensi Laba, Free

Cash Flow, Dan Risiko Litigasi. Jurnal Ilmiah Akuntansi dan Bisnis Vol. 8

No. 2 Juli 2013. 